\title{
Long Term Orientation Moderating Effect on Acceptance of Jogja Smart Service in Countries with Pragmatic Society
}

\author{
J G P Negara ${ }^{1}$ \\ ${ }^{1}$ Department of Informatics, Universitas Atma Jaya Yogyakarta, Indonesia \\ E-mail: julius.galih@uajy.ac.id ${ }^{1}$
}

Submitted: 10 February 2021, revised: 23 February 2021, accepted: 24 February 2021

\begin{abstract}
Abstrak. Pemerintah dan pemangku kepentingan dengan konsep kota pintar dapat memanfaatkan teknologi komunikasi, jaringan yang berkembang pesat hingga saat ini untuk segala kebutuhan tantangan perkotaan. Tantangan pelayanan pemerintah yang harus dipersingkat, dapat memotong jarak, serta keterbukaan informasi dapat mulai teratasi dengan konsep kota pintar dengan berbagai produknya. Model penerimaan teknologi yang dikombinasikan dengan moderator budaya telah digunakan oleh beberapa peneliti untuk pengujian penerimaan, salah satunya adalah penelitian ini. Pengumpulan data penelitian dan survei diolah menggunakan Smart PLS 3.2 dengan Sequential Equation Modeling di Yogyakarta, Indonesia. Hal ini menjadi unik untuk dibahas karena p-value Long Term Orientation (LT) adalah 0,386 yang berarti variable ini tidak memoderasi perilaku secara signifikan. Hal ini menarik untuk disajikan dalam publikasi karena Indonesia merupakan negara dengan nilai orientasi Jangka Panjang yang tinggi atau masyarakat yang pragmatis. Masyarakat pragmatis cenderung lebih fleksibel dalam menyesuaikan tradisi, dengan konteks kekinian, dan mudah beradaptasi. Temuan pendukung kami adalah responden yang pernah mencoba menggunakan JSS masih diperbolehkan menggunakan metode konvensional dalam pelayanan pemerintah.
\end{abstract}

Kata kunci: orientasi jangka panjang, UTAUT2, moderator kultural, kota pintar

\begin{abstract}
The government and stakeholders with the smart city concept can take advantage of communication technology, a network that has grown rapidly to date for all the needs of urban challenges. The challenges of government services that must be shortened, cut distances, and information disclosure can begin to be resolved with the concept of a smart city with its various products. The technology acceptance model combined with the cultural moderator has been used by several researchers for acceptance testing, one of which is this paper. Research and survey data collection were processed using Smart PLS 3.2 with Sequential Equation Modeling in Yogyakarta, Indonesia. This is unique to discuss because the p-value of Long Term Orientation (LT) is 0.386 which means that it does not significantly moderate behavior. This is interesting to be presented in publications because Indonesia is a country with a high Long Term orientation value or a pragmatic society. Pragmatic societies tend to be more flexible in adjusting traditions, with the current context, and easy to adapt. Our supporting findings are that respondents who have tried using JSS are still allowed to use conventional methods in government services.
\end{abstract}

Keywords: long term orientation, UTAUT2, cultural moderators, smart city 


\section{Introduction}

Developing a city from a conventional order to become a smart city with the latest technology can solve various challenges and problems in Indonesia. Smart cities are also presented to overcome coordination problems between various levels of government, as well as between government and society [1]. Today's urban premises are complex systems characterized by large numbers of interconnected citizens, multiple modes of transportation, communication networks, and businesses heading on autopilot. Schematically, the smart concept is the answer to the challenges outlined above. Enabling large numbers of people to connect, meeting the need for appropriate transportation, means of communication without barriers, improving government services, and making some aspects of the lives of "smart" people sustainable. Researching government mobile products or applications that have been run is an interesting area of research.

Smart City is believed by some to be an important strategy to improve the quality of life for people in big cities or urban cities in most countries in the world [2]. A smart scheme is a system that provides significant improvements and enhancements to society, organizations, and government services. Conventional service users have more passive movements compared to current users who are more active, transformative, and more demanding of what they need. The author states that egovernment research, including the concept of smart cities, is very important needed for developing countries as stated by [3].

It is interesting to know the acceptance of the application of smart cities in Indonesia with a pragmatic society. It is true as we all know that pragmatic societies tend to easily adapt to the current situation. This research reveals whether smart city applications will easily be accepted by pragmatic people. The author has examined the acceptance of smart city mobile apps coupled with cultural moderators. In this study, the findings of several important variables from the UTAUT2 model, and Hofstede's moderating culture construct moderately to moderate behavioral intentions. The researcher found that in this study the Long and Short term orientation had a low behavioral intention to moderate the use behavior.

\section{Literature \& Current Studies}

\subsection{Smart City}

The concept of a smart city has been around for a long time. It is estimated that in the 1990s the concept of a smart city was put forward [6]. This concept was raised on the offer as an alternative to conventional, migrated using the latest information communication technology to solve urban problems. The challenges of urban life will meet solutions from a technological point of view. Several perspectives emerge from this concept, the first perspective on urban development must consider the linkages between infrastructure, community, and government and private. Some researchers look holistically at the concept of Smart City in their proposal ideas [6] - [8]. Because this concept is a concept that is sustainable, and contextual with what the community is experiencing, we are interested in this research we conducted in communities with high Long Term orientation values or pragmatic societies.

\subsection{Acceptance Model}

5 models dominate the acceptance models that have emerged [9], Venkatesh in the 2003 era in [10] introduced the UTAUT theory. The five theories include TPR, IDT, AM, TRA, TPB. The research [11] explained about Innovation Diffusion theory. In 1975, the Theory of Reasoned Action was abbreviated as TRA. Also has been described Theory of Planned Behavior in [12]. Until recently the TAM technology acceptance model was often used [13]. Then for the Perception Risk Theory (TPR) is described in publication [13]. Venkatesh in 2003 put forward the integrated theory of acceptance and use of technology [10]. It is building a new, holistic and substantial model for technology acceptance. This below explains the Unified Theory of Acceptance and Use of Technology. 


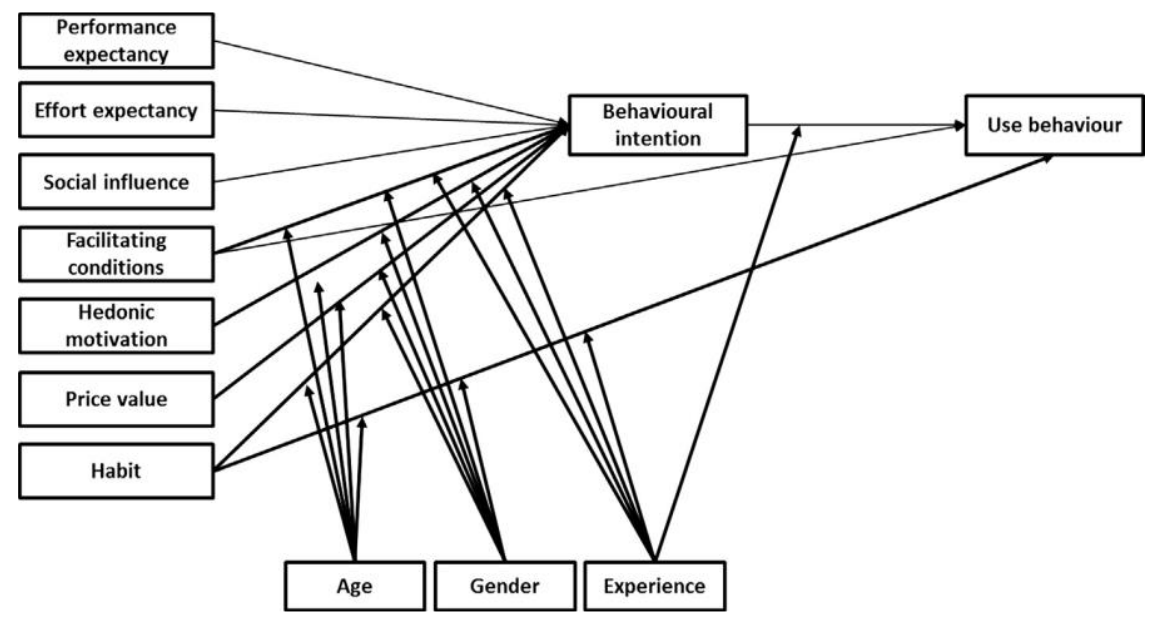

Figure 1. UTAUT2 Model (25)

Venkatesh with the first version of UTAUT proposed four constructs [10], performance expectations, effort expectations, social influence, and facilitation conditions being the final constructs. Since this first appeared, this model has been increasingly in demand by researchers of other technology acceptance. A publication of our research found that UTAUT is implemented to explore the acceptance of cellular technology, and is increasingly being used in research into the use of technology in individuals and organizations in many countries [14].

Venkatesh realized that although the first model was widely used, there were weaknesses or limitations in this model [15]. In 2012 UTAUT2 was raised to answer the challenges of the limitations of the previous model in testing acceptance [16]. In (Figure. 1) describes seven constructs in a complete model at this time. These constructs include: PE performance expectations, EE effort expectations, social influence SI, FC facilitation conditions, HM hedonic motivation, PV price value, and the last is $\mathrm{H}$ Habits. Venkatesh added three constructs that did not exist before. The first predictor construct is hedonic motivation. Because technology users will receive a bill, or pay a certain amount of money for the use of technology, a price value construct is entered. User habits were also viewed and included as predictor constructs.

Age, gender, user experience are moderating variables that influence and eliminate volunteerism from previous UTAUTs. FC is also hypothesized to add a direct relationship to user behavior and behavioral intention. Also, usage behavior has been moderated by experience.

\subsection{Hofstede's Cultural Moderator}

Information systems in their acceptance and use are believed to be influenced also by the culture of the community [14]. In some publications, it has been noted that this needs to be included [17]. It is mentioned because, among those that already exist, cultural values become a moderator in acceptance [18]. We find that in empirical research on cellular technology and culture there is a steady increase. However, only a few researchers combine the two. Viewpoints on cultural definitions can be defined in various ways, such as the way people solve problems.

Hofstede has been praised by other researchers and authors. This is because he opened the eyes of researchers to the importance of the cultural dimension [19]. In his research, he gave several classifications. He explained individualism/collectivism, which means that people can look after themselves or their close relatives and can sort out which ones are more important than personal interests or social interests. Power distance is the second classification, which means that the distribution of power in society is not evenly felt in every element of society. Furthermore, UA uncertainty avoidance is the extent to which people feel ambiguous, threatened by uncertainty, then the community group or you avoid it.

In Indonesia, it is stated as a country with a society that is: hierarchical, collectivist, lowly masculine, low uncertainty avoidance, and long-term oriented. Hofstede and the global company IBM research with its cultural dimensions. In this study, data were collected from at least 50 countries 
collected by. Indonesia is a developing country having the following values: $48 \mathrm{UA}, 14 \mathrm{IC}, 46 \mathrm{MF}, 68$ LT, and 78 in PD [20].

There are some people who B disagree that the cultural dimension is used for purposes other than country-level studies [4]. The point of this person is that it is inappropriate to use the cultural dimension scores in countries to predict individual behavior. But some researchers have used it as a moderator predictor and adopted a cultural dimension to use at the individual level [21].

\section{Research model \& hypotheses}

The author combines (UTAUT2) and Hofstede's cultural moderators, then the combination of the two is used as a theoretical basis for research. If we look at previous research, the UTAUT2 acceptance model resulted in a substantial increase in explaining behavioral intentions and technology use [16]. Because of this, the combination of the two things becomes a model in this study. In the literature we have written above, it is explained that culture affects one's behavior in accepting and using a new information system technology. Hofstede's cultural moderators are our chosen moderator constructs that we use until the information we expect appears.

Performance expectations are the degree of trust of government application users, when they use it, they will get an advantage, which is something they want from the service [1]. This shows that someone will use a mobile application or an information system technology if they believe that they will get a positive result [2]. This construct is one of the most important factors that directly affect acceptance intention [3].

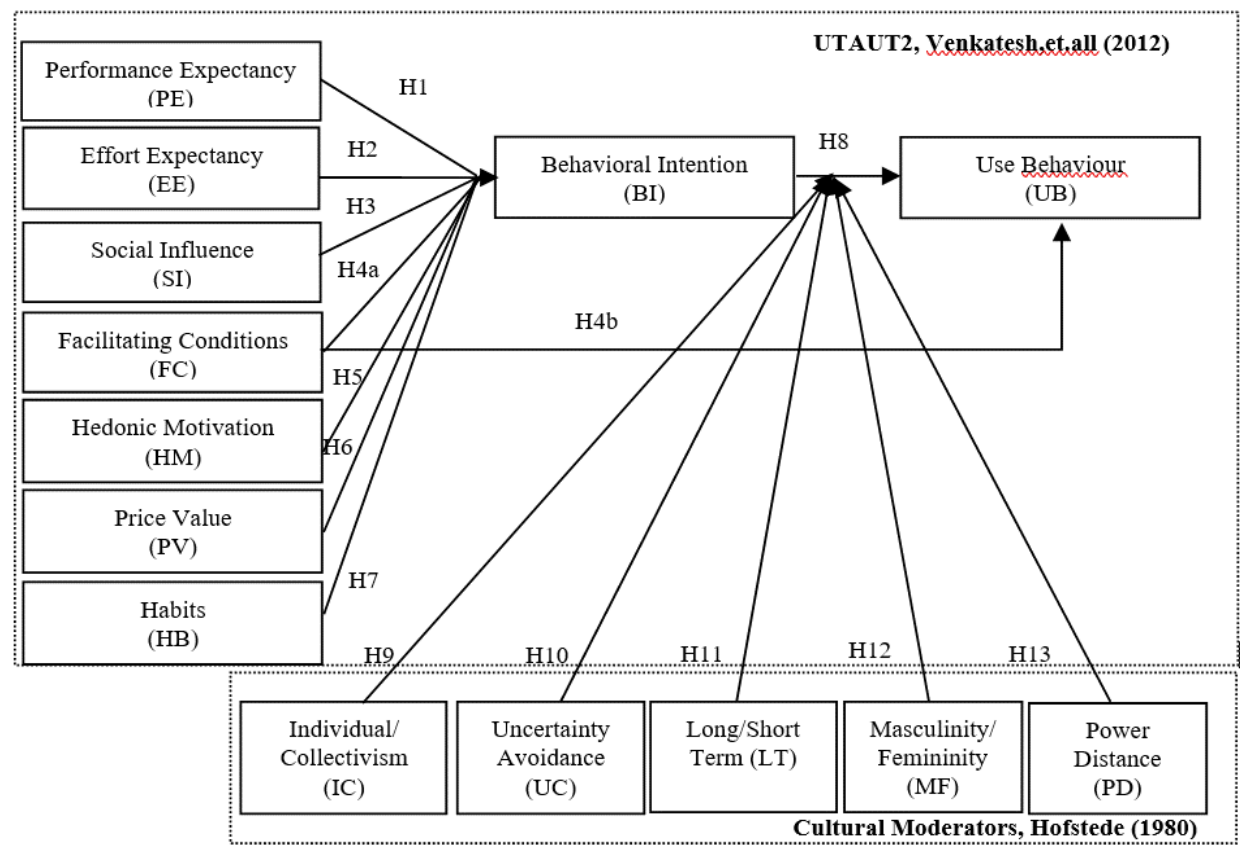

Figure 2. Research model

Effort expectation is related to the degree of ease of a user in using mobile applications. Individuals cannot be separated from the people around them, even though the value of each person and each place is different. Social influence constructs the degree to which a person will be influenced by the people closest to him, or those around him in using smart city applications. The facilitating condition is the degree to which people with the facilities that they have can use the applications they install, including government applications. Requires some experience using internet services with a mobile phone or tablet, installing a mobile application on their device in using the smart city/e-government mobile application service [1]. Hedonic motivation is the degree of a person's happiness and unsaturation factors that are obtained after using information technology[4]. This is an important 
construct in assessing technology acceptance[5]; if the entertainment provided or the happiness brought by an information system application, the greater one's intention to accept and use[6].

The price value regarding the benefits and the nominal price that the user must pay when using the mobile application [4], includes the nominal internet fee, application service fee, and all prices that the user must pay. The price value becomes positive, the cost of use is not greater than the benefits obtained. Habit is a reflection of the previous behavior of the user [4] and the frequency of the usage behavior was considered by previous researchers as a determinant of current behavior [7]. Based on the psychological theory stated that all models are consistent, with a statement that individual intentions can predict and influence individual behavior[8], UTAUT2 supports the belief that behavioral intention has a major influence on the use of technology [1].

Long-term orientation or abbreviated as LT is something related to tradition, the harmony of individuals in society, and thinking about the future of an individual or group [47]. Indonesia as a developing country has high value. This country has a score of 62 . This value shows that this country has a pragmatic culture. A group of people with the pragmatic orientation category believes the truth is very dependent on the community situation, the context for something happening, and the time when it happens. Pragmatic societies can easily adapt their traditions to dynamic conditions. Pragmatic societies have a strong intention to save and invest and are persistent if they have a plan [34].

Therefore we have a hypothesis that Long / Short Term (LT) can moderate behavioral intentions (BI) on usage behavior (UB), people with high long-term orientation values have a higher moderation relationship.

\section{Data collections and research methodologies}

Yogyakarta is one of the cities that has implemented a smart city policy in Indonesia. Researchers conducted data collection in this city. In the implementation of the application of JSS as a smart city application, there is no obligation for the community to use it or other compelling reasons from the government. The questionnaire which is the reference of this study is in English and has been reviewed for its validity by a group of academics.

We translated the questionnaire into Indonesian. We also work closely with academics who graduated from the English Language Study Program to review the translation results and adjust them to the Indonesian context. Together with different people, we translated the questionnaire back into English to ensure consistency [9].

This research has two parts. The first major part of UTAUT2 is a model of a collection of technology acceptance constructs. The second is culture as a parameter, then to complement we include general information. The items and scales for the UTAUT2 construct were adapted from [1], [4], usage behavior from [10], and the long-short term of [11]. Each item was measured on a five-point Likert scale, ranging from 'strongly disagree' (1) until 'strongly agree' (5). Martins wrote coded usage behaviors from 1 (never) to 11 (multiple times per day) [10], according to the effectiveness of using JSS.

The survey was conducted by distributing questionnaires to research targets. We were inspired by a study that with our target criteria a questionnaire survey was carried out [1]. Thirty users of Jogja Smart Service were used by researchers to test this survey. The number of thirty is not included in the final data processing. Validity and reliability are indicated by a scale for preliminary evidence. When the research was conducted it was quite difficult to find respondents, so snowball sampling was used. This intends to make it easier to find respondents who use this application in distributing questionnaires. The facts show that not all the people of Yogyakarta City JSS when the research was taking place. Researchers decided to use this method to get recommendations for who has used this mobile application.

Table 1. Descriptive statistic of respondents

\begin{tabular}{llrl}
\hline Measure & Value & Frequency & \% \\
\hline M/F & Male & 180 & 64 \\
& Female & 101 & 36 \\
Age & $\leq 35$ & 168 & 60
\end{tabular}




\begin{tabular}{llrr}
\hline Measure & Value & Frequency & \% \\
\hline & $36 \geq \leq 50$ & 88 & 31 \\
& $\geq 51$ & 25 & 9 \\
Respondent & & 180 & 64 \\
Education & Lower than bachelor & 96 & 44 \\
& Bachelor & 5 & 2 \\
SUF & Master or higher & & \\
Smartphone & & 0 & 0 \\
Use frequency & $\leq 60$ Minutes/day & 43 & 15 \\
& $60-180$ minutes/day & 107 & 38 \\
& $180-300$ minutes/day & 121 & 43 \\
& $300-420$ minutes/day & 10 & 4 \\
& $\geq 420$ minutes / day & & \\
IUF Internet & $\leq 60$ Minutes/day & 0 & 0 \\
Use Frequency & 14 & 5 \\
& $60-180$ minutes/day & 96 & 34 \\
& $180-300$ minutes/day & 147 & 52 \\
& $300-420$ minutes/day & 24 & 9 \\
\hline
\end{tabular}

During 12 weeks, a total of 281 good feedback from respondents. To see the distribution of samples, the Kolmogorov-Smirnov (K-S) test was carried out. We do verification and we make sure that it is not statistically different. The non-response bias was stated to be absent. Statistically, descriptive Table 1 presents the respondent's data and is described in detail.

\section{Result}

SEM stands for Structural Equation Modeling. It is used by the authors to describe the statistical model used to evaluate the validity of substantive theory with empirical data, which has also been used several times [12]. Two covariance-based and variant-based techniques are currently available. The writer used variant-based techniques to perform theoretical tests. The software application we use for this test is Partial Least Square (PLS) which is called SmartPLS 3.0. When research is faced with many constructs and complexes, it is an excellent statistical technique and is considered suitable for many research situations [13].

PLS can be considered adequate for estimation. We aimed to construct sample dimensions that were ten times larger than the maximum path [14]. When compared to covariance-based techniques, this technique is known to have minimal limitations in terms of sample size and residual distribution. Guidelines were followed, and analysis was carried out in two steps [15]; We begin with an assessment of the reliability and validity of the measurement model, followed by an assessment of the structural model and testing the hypothesis. Below are described the two steps.

\subsection{Model Measurement}

Convergence validity, construct reliability, reliability indicators, and discriminant validity was included in the measurement model. We provide information about Average variance extracted AVE, CR which means composite reliability abbreviated, CA which means abbreviated Cronbach Alpha, t-value, and also loadings. All composite constructions and reliability, as shown by the table we present, CA value greater than 0.7 indicates construction reliability [16]. The load must be higher than 0.7 and the reliability of the indicator is evaluated based on the criterion that any load below 0.4 must be removed [17]. Due to low loadings factors, some are removed. those having a value of 0.7 or higher are the 
remaining loads and are statistically significant at 0.05 . Convergence validity test with AVE, then all constructs are compared. The minimum acceptable values of 0.50 [18] and [13] are shown in Table 2.

Discriminant validity was analyzed using cross-loading factors and Fornell-Larcker criteria. Instead of every cross-loading on another factor, each item presents a higher load on the appropriate factor. Multiple items must be removed from each variable to ensure cross-loading criteria. The evidence of the validity of the discriminant scale is proven because two criteria are met in the end. It is confirmed that the constructs are statistically different and can be used to test the structural model. This is because the discriminant validity, convergence validity, indicator reliability, good construct reliability are shown from the measurement results of the model.

Table 2. Factor loadings and quality criteria

\begin{tabular}{|c|c|c|c|c|c|c|}
\hline Construct & AVE & $\begin{array}{l}\text { Composite } \\
\text { reliability }\end{array}$ & $\begin{array}{c}\begin{array}{c}\text { Cronbach's } \\
\text { Alpha }\end{array} \\
\end{array}$ & Item & Loadings & t-value \\
\hline \multirow{2}{*}{$\mathrm{PE}$} & \multirow{2}{*}{0,835} & \multirow{2}{*}{0,910} & \multirow{2}{*}{0,802} & PE3 & 0,909 & 23,488 \\
\hline & & & & PE4 & 0,918 & 26,161 \\
\hline \multirow{2}{*}{$\mathrm{EE}$} & \multirow{2}{*}{0,855} & \multirow{2}{*}{0,921} & \multirow{2}{*}{0,884} & EE1 & 0,995 & 1,659 \\
\hline & & & & EE4 & 0,848 & 0,296 \\
\hline \multirow{2}{*}{ SI } & \multirow{2}{*}{0,849} & \multirow{2}{*}{0,918} & \multirow{2}{*}{0,823} & SI1 & 0,936 & 20,901 \\
\hline & & & & $\mathrm{SI} 3$ & 0,905 & 20,667 \\
\hline \multirow{2}{*}{$\mathrm{FC}$} & \multirow{2}{*}{0,914} & \multirow{2}{*}{0,955} & \multirow{2}{*}{0,906} & $\mathrm{FC} 1$ & 0,950 & 33,633 \\
\hline & & & & $\mathrm{FC} 2$ & 0,962 & 32,924 \\
\hline \multirow{2}{*}{$\mathrm{HM}$} & \multirow{2}{*}{0,822} & \multirow{2}{*}{0,902} & \multirow{2}{*}{0,787} & HM1 & 0,933 & 11,448 \\
\hline & & & & HM2 & 0,879 & 8,190 \\
\hline \multirow{2}{*}{$\mathrm{PV}$} & \multirow{2}{*}{0,914} & \multirow{2}{*}{0,955} & \multirow{2}{*}{0,906} & PV1 & 0,958 & 31,260 \\
\hline & & & & PV2 & 0,954 & 35,083 \\
\hline \multirow{2}{*}{ HB } & \multirow{2}{*}{0,860} & \multirow{2}{*}{0,924} & \multirow{2}{*}{0,837} & HB2 & 0,923 & 28,534 \\
\hline & & & & HB3 & 0,931 & 27,999 \\
\hline \multirow{2}{*}{ BI } & \multirow{2}{*}{0,899} & \multirow{2}{*}{0,947} & \multirow{2}{*}{0,887} & $\mathrm{BI} 2$ & 0,952 & 52,669 \\
\hline & & & & $\mathrm{BI} 3$ & 0,944 & 71,726 \\
\hline \multirow{2}{*}{$\begin{array}{c}\text { Long/Short } \\
\text { Term }\end{array}$} & \multirow{2}{*}{0,814} & \multirow{2}{*}{$\mathbf{0 , 8 9 7}$} & \multirow{2}{*}{0,771} & LT2 & 0,889 & 16,282 \\
\hline & & & & LT4 & 0,915 & 17,749 \\
\hline
\end{tabular}

Table 3. Path coefficient and their significance

\begin{tabular}{cccccc}
\hline & $\begin{array}{c}\text { Original } \\
\text { Sample (O) }\end{array}$ & $\begin{array}{c}\text { Sample } \\
\text { Mean (M) }\end{array}$ & $\begin{array}{c}\text { T Statistics } \\
(\mid \mathbf{O} / \text { STDEV })\end{array}$ & p-values & Results \\
\hline SI-BI & 0,239 & 0,237 & 5,457 & 0,000 & Supported \\
\hline FC- BI & 0,284 & 0,29 & 4,477 & 0,000 & Supported \\
\hline FC-UB & $-0,05$ & $-0,052$ & 1,083 & 0,279 & Not Supported \\
\hline $\begin{array}{c}\text { Moderator } \\
\text { LT }\end{array}$ & $-0,033$ & $-0,03$ & 0,867 & 0,386 & Not Supported \\
\hline
\end{tabular}




\subsection{Hypotheses testing and structural model}

Hypothesis analysis and relationship building become the basis for examining the standard pathway. Path significance levels were estimated using bootstrap resampling [13], resampling with 500 iterations. The authors summarize the results in Table $4.57 .2 \%$ variation in behavioral intention and $72.4 \%$ in user behavior as described in this model. Statistically, it appears with a p-value $<0.01$, namely the intention to behave and the behavior of use is moderated by uncertainty avoidance. Long-term orientation affects acceptance with a low score to be our finding. This is what makes it so interesting to us.

\section{Discussion}

The UTAUT2 technology acceptance model, by Venkatesh [4], combined with the Hofstede culture moderator [19], in our opinion produces a unique model, which can explain the acceptance of this research object. Each stage carried out by the researcher is expected to find out whether how culture moderates the use of JSS.

\subsection{Main findings}

When the research and data processing was completed, an interesting thing was found. In some of the above, constructs that moderate behavioral intentions are shown and which do not moderate positively. Surprisingly, long-term orientation did not affect usage behavior intention towards usage habits. The Pvalue of the LT captured from this study was 0.386. What does this mean in value? These P-values neither support nor positive moderation of behavioral intentions for user behavior. Our initial suspicion was that the study was conducted when the release of this application had only been carried out for one year and conventional government services were still around. Users are still free not to use this JSS application.

State with high long-term orientation values is considered pragmatic societies that will easily adapt their traditions to the current conditions. However, this application has only been released and developed gradually. According to researchers, this value will be dynamic and can change over time the research is carried out. It is possible that when traditional government services are no longer available, everything will be transferred to a digital platform based on research results.

People with a high long-term orientation are classified as pragmatic. This type of society is believed to be more adaptable to ongoing conditions. They will see everything that is faced according to the context of the place and time. In connection with the acceptance of this smart city application, the Indonesian people will easily accept this software. However, this research also reveals that the longterm orientation has a low moderation effect in influencing acceptance. This is reinforced by the fact that the public can still use conventional government services other than JSS.

The most important finding of this study is that UC significantly impacts or influences behavioral intention. This research is interesting to do for users when there are no government services other than the integrated JSS application. With that, we hope that the next research can reveal more factually. The government should be confident in releasing this mobile application. Because Indonesian society is a society that is flexible in accepting a change.

\subsection{Supported findings}

A construct of significant significance which is one among all cultural moderators is UC. In [20], it states that people tend to be relaxed to accept new costs including technology in areas with low uncertainty avoidance so that these people are happy and will more easily accept new technology [21]. By the fact that Indonesia is the main market for world technology companies. Indonesians will not hesitate to switch to new technology.

Some citizens will choose the latest technology according to the software application they want. Rather than facing conventional public service challenges by governments, they chose to use the latest technology for uncertainty avoidance. This matter should not be overlooked by the government that 
people use smart city mobile applications, one of the goals is to avoid uncertainty, or disclosure of information, and fast service [22].

People are shifting from conventional services to new services because technology provides tantalizing deals for solving various challenges. Because this application can be accessed from anywhere and anytime, people who were reluctant to do government services in the past will immediately switch to this application. Services that do not bore people and are better according to users are a special attraction for a government service [6].

Research with a model that we have duplicated from previous studies, validates the influence of cultural moderators on BI and UB. However, while LT was found not to affect significantly as in other studies for applications that already have a lot of users.[23].

\subsection{Additional Findings}

Researchers started the questionnaire collection stage when the Jogja smart service application was in the introduction stage by the government. We can predict that not all people are aware of this mobile application. Even though the government has initiated the use of this application alongside conventional services, not all people have switched to using it. Few users have installed this application when compared to the number of people in Yogyakarta. Those who have installed are revealed to have followed the advice of the government, or someone close to them who has benefited from using the software. People who have experienced the benefits of installing this app on their smartphone will likely advise others nearby. Then other people might put up because it is easy for us in Indonesia to adjust to new habits or cultures.

In opposite with previous researchers or authors, we state that not all UTAUT2 constructs affect the behavioral intentions of technology use. The Indonesian people are deemed proficient and accustomed to using technology, so they will easily accept this application. Effort expectancy does not have a positive effect. In this study, it was found that social influences can influence the community in installing and using the JSS application [24]. The findings of SI which are stated to affect Indonesia also need to be drawn in a straight line with the results of the LT value which has no significant effect on the habit of using applications. One day when this application is finished the introduction stage and is used by many people and the number of respondents is getting wider, it needs to be reviewed whether LT has a higher impact on usage. The collectivist and pragmatic Indonesian society should accept opinions and input because they are close to society and flexible to implement changes, the society can play a big role for the people [10].

\section{Conclusions}

This research informs us that long-term orientation is not a significant variable. It is estimated that this happened because the mobile software at the time of the research was still in the implementation stage. The government is moving to mobile apps from traditional services. This affects the number of users who are still small, and users have not made recommendations. Uncertainty avoidance has the highest number in the use of moderation, societies with low avoidance are sure to try, a new smartphone or computer technology. This is like confirming some studies that personal user impact can be affected by end-user computing satisfaction such as this study [25]. However, a pragmatic society with evidence of high long-term orientation values should be able to easily adjust to the use of new technology. In this study, it was shown that this did not affect acceptance.

There is evidence to suggest that people are motivated to use because they seek certainty in government services that is the high value of UC in influencing usage intention on usage habits. research combining technology acceptance models with cultural constructs like this can be used to supplement knowledge to prevent further failure of technology application [25]. The next research that might be done is to collect respondents when there are many application users. Research needs to be done when all services have been carried out using this application and there are no more traditional services for a feature in the application. This study makes a positive contribution to the acceptance of the use of 
applications that are made and introduced to the public. The government can evaluate the promotion of application use. For further projects, the government can make this a benchmark or evaluation material.

\section{References}

[1] F. D. Venkatesh, Viswanath. Morris, Michael G. Davis, Gordon B. Davis, "User Acceptance of Information Technology: Toward a Unified View," Microvasc. Res., vol. 27, no. 3, pp. 425478, 2003, doi: 10.1006/mvre.1994.1019.

[2] C. A. Compeneau, D. R.Higgins, "Development of a measure and initial test," Manag. Inf. Syst., vol. 19, no. 2, pp. 189-211, 2012.

[3] X. Luo, H. Li, J. Zhang, and J. P. Shim, "Examining multi-dimensional trust and multi-faceted risk in initial acceptance of emerging technologies: An empirical study of mobile banking services," Decis. Support Syst., vol. 49, no. 2, pp. 222-234, 2010, doi: 10.1016/j.dss.2010.02.008.

[4] V. Venkatesh, J. Y. . Thong, and X. Xu, "Consumer Acceptance and Use of Information Technology: Extending the Unified Theory of Acceptance and Use of Technology," MIS Q., vol. 36, no. 1, p. 157, 2012, doi: 10.2307/41410412.

[5] H. van der Heijden, "User Acceptance of Hedonic Information Systems," MIS Q., vol. 28, no. 4, pp. 695-704, 2004.

[6] L. Zhang, J. Zhu, and Q. Liu, "A meta-analysis of mobile commerce adoption and the moderating effect of culture," Comput. Human Behav., vol. 28, no. 5, pp. 1902-1911, 2012, doi: 10.1016/j.chb.2012.05.008.

[7] I. Ajzen, "Personality and Social Psychology Review," Personal. Soc. Psychol. Rev., vol. 6, no. 2, pp. 123-151, 2002, doi: 10.1207/S15327957PSPR0602.

[8] C.-S. Yu, "Factors affecting individuals to adopt mobile banking: Empirical evidence from the UTAUT model," J. Electron. Commer. Res., 2012, [Online]. Available: http://refhub.elsevier.com/S0747-5632(15)00311-8/h0460.

[9] R. W. Brislin, Back translations for cultural research. 1970.

[10] C. Martins, T. Oliveira, and A. Popovič, "Understanding the internet banking adoption: A unified theory of acceptance and use of technology and perceived risk application," Int. J. Inf. Manage., vol. 34, no. 1, pp. 1-13, 2014, doi: 10.1016/j.ijinfomgt.2013.06.002.

[11] M. Hassan, E. Shiu, and G. Walsh, "A multi-country assessment of the long-term orientation scale," no. Unit 07, pp. 1-5, 2011.

[12] C. M. Ringle, S. Wende, and A. Will, "Smart PLS 3.0." 2019, [Online]. Available: https://www.smartpls.com/downloads.

[13] J. Henseler, C. M. Ringle, and R. R. Sinkovics, "The use of partial least squares path modeling in international marketing," Adv. Int. Mark., vol. 20, no. 2009, pp. 277-319, 2009, doi: 10.1108/S1474-7979(2009)0000020014.

[14] D. Gefen and D. Straub, "A Practical Guide To Factorial Validity Using PLS-Graph: Tutorial And Annotated Example," Commun. Assoc. Inf. Syst., vol. 16, no. July, 2005, doi: 10.17705/1cais.01605.

[15] J. C. Anderson and D. W. Gerbing, "Structural Equation Modeling in Practice: A Review and Recommended Two-Step Approach," Psychol. Bull., vol. 103, no. 3, pp. 411-423, 1988, doi: 10.1037/0033-2909.103.3.411.

[16] D. Straub, "Validating Instruments in MIS Research," MIS Quart., vol. 13, pp. 147-169, 1989.

[17] G. A. Churchill, "A Paradigm for Developing Better Measures of Marketing Constructs," J. Mark. Res., vol. 16, no. 1, p. 64, 1979, doi: 10.2307/3150876.

[18] C. Fornell and D. F. Larcker, "Evaluating Structural Equation Models with Unobservable Variables and Measurement Error," J. Mark. Res., vol. 18, no. 1, p. 39, 1981, doi: $10.2307 / 3151312$.

[19] G. Hofstede, Culture's consequences: International differences in work-related values. Beverly Hills: Sage Publications, 1980.

[20] G. Hofstede, "The Hoftsede Insight," 2019. https://www.hofstede- 
insights.com/country/indonesia/.

[21] I. P. L. Png, B. C. Y. Tan, and K. L. Wee, "Dimensions of national culture and corporate adoption of IT infrastructure," IEEE Trans. Eng. Manag., vol. 48, no. 1, pp. 36-45, 2001, doi: 10.1109/17.913164.

[22] D. Gilbert et al., "Transforming Government: People, Process and Policy Article information:," 2009.

[23] M. Srite and E. Karahanna, "The Role of Espoused in Technology Values National Cultural," Mis Q., vol. 30, no. 3, pp. 679-704, 2006.

[24] A. Ben Zakour, "Cultural Differences and Information Technology Acceptance," South. Assoc. Inf. Syst., pp. 156-161, 2004.

[25] T. Choi and S. M. Chandler, "Knowledge vacuum: An organizational learning dynamic of how e-government innovations fail," Government Information Quarterly, vol. 37, no. 1. 2020, doi: 10.1016/j.giq.2019.101416. 